\title{
Otaria flavescens and Arctocephalus australis abundance in poorly known sites: a spatial expansion of colonies?
}

\author{
Diana Szteren*
}

\author{
Departamento de Ecología y Evolución. Facultad de Ciencias, Universidad de la República \\ (Iguá 4225, Montevideo 11400, Uruguay) \\ *Corresponding author: diana@fcien.edu.uy \\ Financial Support: DukeUniversity Marine Lab/Oak Foundation's Mini-grants in Marine Conservation program
}

\begin{abstract}
The establishment of new pinniped colonies is a consequence of complex dynamics in which some colonies may transform from haul-outs into breeding sites. The aim of this article was to estimate the abundance of Otaria flavescens and Arctocephalus australis at two poorly known sites of Uruguay, the easternmost "Isla Verde-Islote Coronilla" (IV-IC) and the westernmost "Las Pipas" (LP). From June 2008 to June 2009 count from boats were conducted at LP, and aerial censuses at Isla Verde. At LP both pinniped species were recorded, and the abundance was maximum in July with a total of 202 animals. O. flavescens was present throughout the year, mainly adult males, while $A$. australis was only observed from June to October. LP is defined as a haul-out structure used as resting area, especially for $O$. flavescens. At IV-IC between 225 and $521 O$. flavescens were recorded. The number of animals increased in Spring and Summer. Females were the most abundant category and pups were recorded in March. According to the age structure and the presence of pups, we propose it would have and incipient reproductive activity. This colony should be monitored in relation with its category as a marine protected area.
\end{abstract}

Descriptors: Colonies, Haul-out, Otaria flavescens, Arctocephalus australis, Uruguay.

\section{RESUMO}

A formação de novas colônias de pinípedes é uma consequência da dinâmica complexa na qual algumas delas podem ser transformadas de colônias de descanso em áreas de reprodução. O objetivo deste estudo foi estimar a abundância de Otariaflavescens e Arctocephalus australis em duas áreas pouco conhecidas no Uruguai "Isla Verde-Islote Coronilla" (IV-IC), a mais oriental, e "Las Pipas" (LP), a mais ocidental. As contagens foram feitas de barco em LP e levantamentos aéreos em IVIC de junho de 2008 a junho de 2009. Em LP, foram registradas ambas as espécies de pinípedes, com a maior abundância em julho, num total de 202 animais. $O$. flavescens esteve presente durante todo o ano, e foram registrados principalmente machos adultos, enquanto que $A$. australis apenas foi observada a partir de junho até outubro. LP foi definido, então, como sendo uma colônia de descanso, especialmente para $O$. flavescens. No IV-IC, foram contados entre 225 e 521 indivíduos de $O$. flavescens. O número de animais aumentou na primavera e verão. A categoria mais abundante foi a das fềmeas e ocorreu em março. De acordo com essa estrutura de idade e a presença de prole, propõe-se que a área teria uma atividade de reprodução incipiente. Sugerimos que essa colônia deveria ser monitorada como parte de sua inclusão numa área marinha protegida.

Descritores: Colônias, Colônia de descanso, Otaria flavescens, Arctocephalus australis, Uruguai. 


\section{INTRODUCTION}

The formation of new pinniped colonies is a consequence of complex dynamics involving dispersal, phylopatry, available suitable habitat and reproductive success in different structure contexts (GRANDI et al., 2008). The process consists of the formation of small breeding areas inside haul-out sites, with the arrival of young adult males in juvenile areas (CRESPO, 1988). The mechanisms involve higher survival rates of juveniles, available space for individuals starting to reproduce, the quality of feeding areas, and density-dependent factors limiting the number of sea lions reproducing in the wellestablished breeding areas (RAUM-SURYAN et al., 2002, DANS et al., 2004). Thus, some colonies are of a dynamic nature, admitting the possible transformation from haulouts into breeding sites. The establishment and growth of breeding or haul-out areas may indicate a change in distribution, an expansion of the colony and represent the key to the recovery of depressed populations.

Pinniped colonies may be described as breeding areas when reproductive activities take place there (i.e. when there occur the formation of harems, reproductive territories and births), or non-reproductive haul-out sites which some animals use for resting but where no reproduction takes place. There are permanent and seasonal colonies, depending on whether there are pinnipeds present throughout the year or only during some periods of it. Haul-out sites may be those occupied permanently by a mixed population, Winter haul-outs - occupied by juveniles and adults, male haul-outs, or occasional haulouts (with the occasional arrival of some animals, with inter-annual variations) (LEWIS and XIMÉNEZ, 1983; GRANDI et al., 2008). There are also mixed structures of small breeding areas with a large number of juveniles or non-reproductive animals in close proximity (XIMÉNEZ and SCOLARO, 1974; GRANDI et al., 2008).

On the Uruguayan coast two pinniped species breed sympatrically, the Southern sea lion (Otaria flavescens) and the South American fur seal (Arctocephalus australis). As Otarids, these two species have a polygynic reproductive system. Males fight to defend their sites and establish harems of several females. The breeding season of A. australis starts before the end of October with the establishment of the territorial adult males that come from the feeding areas. Births take place from the end of November to the end of December (PONCE DE LEÓN et al., 2000). The adult males of $O$. flavescens start arriving at the rookeries by the end of November and in December. Usually the least active or immature males stay outside the breeding area. Gravid females arrive and establish territories between mid-December and the beginning of January. Mating occur from midDecember to mid-February and the maximum number of births occurs in mid-January. The breeding season ends by the end of February (CAMPAGNA, 1985). When sea lion pups are one week old, their mothers start to alternate feeding trips of 2-3 days with periods of presence on land. During a breeding season there is a marked daily variation in the number of animals of both species on land and this decreases in the hours in which temperatures are higher (BIANCO and VAZ-FERREIRA, 1993).

Both species breed and rest throughout the year in four areas: Isla and Islote de Lobos ( $\left.35^{\circ} 01^{\prime} \mathrm{S}-54^{\circ} 53^{\prime} \mathrm{W}\right)$ where a large portion of the fur seal population breeds, the Torres

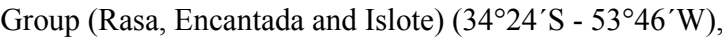
and the Castillo Grande group (Marco and Seca Islands) $\left(34^{\circ} 21^{\prime} \mathrm{S}-53^{\circ} 45^{\prime} \mathrm{W}\right)$. Additionally, O. flavescens breeds at the La Coronilla group (Verde Island and Coronilla Islet) (335' S - 58²9’W) (VAZ-FERREIRA, 1956) (Figure 1). The first two areas have been monitored since 1950 (VAZFERREIRA, et al. 1984), and counted on a yearly basis since 1994 by the National Aquatic Resources Authority (DINARA). Both species show different abundances and contrasting trends in Uruguay: $O$. flavescens numbers around 10 000-12 000 animals and is declining at an annual rate of $1.7 \%$, whereas $A$. australis comprises 300 000 animals and its population is growing around $2 \%$ annually (DIRECCIÓN NACIONAL DE RECURSOS ACUÁTICOS, 2012; PÁEZ, 2006).

Recent data showed that while sea lion birth rates at Isla de Lobos have steadily declined between 1995 and 2004, at the Torres group they have increased since 1995 (PÁEZ, 2006). Two areas seem to be hosting more animals than in the past. The first, "Las Pipas" (3454'29"S and $\left.56^{\circ} 01^{\prime} 34^{\prime \prime} \mathrm{W}\right)$ is located in the Rio de la Plata estuary near Montevideo. This colony has been mentioned as a nonbreeding sea lion's site (VAZ-FERREIRA, 1982) but no numbers have ever been published. During recent years fishermen have reported an increase in the number of sea lions and the presence of fur seals in the area. However, this colony may have an important role as a resting area for subadults and adults in Winter or for mother-pup pairs.

The second colony, "Isla Verde-Islote Coronilla" $\left(33^{\circ} 56^{\prime} 28^{\prime \prime} \mathrm{S}\right.$ and $53^{\circ} 29^{\prime} 18^{\prime \prime} \mathrm{W}$ ) of the Coronilla group, is the easternmost one on the Uruguayan coast and is the northern 


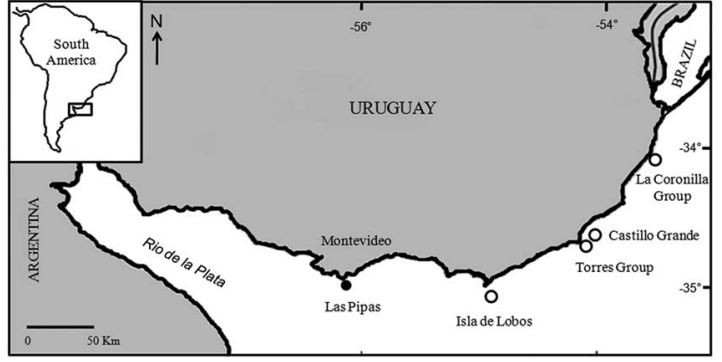

Figure 1. Map of the coast of Uruguay showing all the Pinniped groups of Islands

limit of breeding sites of Southern sea lions in the Atlantic Ocean (VAZ-FERREIRA, 1956). This colony has scarcely ever been counted in the past. In 1953 the birth of 516 pups of $O$. flavescens was reported, and in 1975 the number of newborn pups had decreased to 100 (VAZ-FERREIRA, 1982). In January 1977 on Isla Verde, only 24 adults and 4 pups were recorded and an "imminent extermination" was mentioned (PILLERI and GIHR, 1977). However in that study, Coronilla islet was not sampled. The last published report on the abundance at the La Coronilla Group was in 1995, when 244 adults and subadults were recorded in Winter and 31 pups in Summer (PONCE DE LEÓN, 2000). Since then no data of abundance of pinnipeds has been recorded, as these islands are not included in the annual population abundance estimations carried out by DINARA. In December 2008, January and April 2009 three counts were made from a boat around Isla Verde and Islote La Coronilla (LEZAMA and SZTEREN, 2009) where 93, 136 and 82 animals were counted respectively; 20 pups were observed in January and 11 in April. Nevertheless, the contribution of this area to the total sea lion population is still uncertain.

In Patagonia, Argentina, the founding of new colonies was related to the expansion and increase of the population. Animals would disperse from dense breeding sites to new suitable sites nearby (GRANDI et al., 2008). In Uruguay, to the east of the "Torres" and "Castillo Grande" groups the single island is Isla Verde-Islote Coronilla. We hypothesize that despite the overall declining population in Uruguay, a geographical expansion process of $O$. flavescens may be occurring slowly and other sites receiving more animals than in the past.

At the present time, DINAMA is implementing a National System of Protected Areas (SNAP), whereby La Coronilla-Cerro Verde Marine Protected Area (MPA) (Law $\left.\mathrm{N}^{\circ} 17.234 ; 2000\right)$, which includes "Isla Verde", would be the first MPA to be established in Uruguay (MINISTERIO DE VIVIENDA, ORDENAMIENTO TERRITORIAL Y MEDIO AMBIENTE, 2011). It is crucial to collect information about sea lion seasonal abundance for the design and implementation of conservation and management plans within the MPA. Estimates of abundance will be used to assess the importance of these colonies in terms of the whole Uruguayan stock.

The aims of this study were to estimate the abundance of Southern sea lions and South American fur seals in two poorly known areas in Uruguay, "Isla Verde" and "Las Pipas", and to determine their seasonal changes and social composition.

\section{MATERIAL AND METHODS}

LAS PIPAS

Las Pipas (LP) is a small colony situated on the boundary between Montevideo and Canelones Departments. It is located approximately $2.79 \mathrm{~km}$ from the coast. Eight trips were conducted onboard artisanal fishing boats on June $9^{\text {th }}$, July $9^{\text {th }}$, October $5^{\text {th }}$, November $23^{\text {th }}$, December $31^{\text {st }} 2008$, February $4^{\text {th }}$, May $3^{\text {rd }}$, and June $7^{\text {th }}$ of 2009 . Due to bad weather conditions no trips could be made in August and September 2008. The boat traveled around islets and rocks, getting between the islets to count all the animals. The mean distance from the animals was of around $30 \mathrm{~m}$. Two observers counted seals and sea lions. Counts were made in the morning ( $\sim 9.30 \mathrm{am})$ to ensure the presence of the maximum number of animals resting at the colony (BIANCO and VAZ-FERREIRA, 1993) and depending on the opening of the flying club.

Animals were classified in the following sex-age categories: adult males, subadult males, females, juveniles and pups. They were classified by morphologic external characters together with the typical behavioral patterns observed (SAN FELICE et al., 1999). Additionally, we have incorporated a category of "undetermined" for animals whose age and sex it was impossible to determine because they were not clearly sighted.

\section{Isla Verde- Islote Coronilla}

La Coronilla group (IV-IC) consists of a main island (Isla Verde,) at $1.45 \mathrm{~km}$ from the coast and Coronilla Islet to the East (Fig. 1). They are separated from each other by a $300 \mathrm{~m}$ wide channel (VAZ-FERREIRA, 1956). At this rookery the methodology chosen was the aerial census because previous visits by boat indicated that many areas are not visible from the sea. The methodology consisted in performing an estimation of abundance by direct count on aerial photos. 
Trips to Isla Verde were conducted on June $1^{\text {st }}$, July $18^{\text {th }}$, September $27^{\text {th }}$, November $20^{\text {th }} 2008$ and January 3, February $7^{\text {th }}$, and March $26^{\text {th }} 2009$. No trips could be undertaken in August, October, and December 2008 due to weather conditions and technical problems with the plane. Aerial censuses were conducted by a small aircraft (Continental O-200A, Register CX-BFA) at a constant speed of $100 \mathrm{mph}$. Aerial trips were always conducted early in the morning, because of the better weather conditions. Once the aircraft reached the area, it descended to $120 \mathrm{~m}$ altitude and made between 4 and 6 circuits around the whole area taking photographs, in order to cover the whole surface from different angles. The pictures were taken with a digital camera Nikon coolpix P80 with $10 \mathrm{MP}$ and 18x optical wide-angle zoom.

Photographic censuses are an adequate tool for undertaking direct counts, especially for marine mammals that congregate densely and in high numbers (EBERHARDT et al., 1979). Once the photographs arrived at the laboratory the animals were counted using the "method of direct counts by multiple observers" by two independent researchers 3 times. Then the final number was agreed on (EBERHARDT et al., 1979; EFFORD and DAWSON, 2009).

\section{CORRECTION FACTORS}

Censuses may underestimate the population size because an unknown proportion of the animals are in the sea, or due to environmental (e.g., tide height, time of day) and surveyrelated effects (e.g., animals not seen or clearly identified in aerial pictures) (DANS et al., 2004; SEPÚLVEDA et al., 2011). Additionally, it is important to consider the circadian rhythms of these species, which are given by feeding habits and thermoregulatory behaviour (BIANCO and VAZ-FERREIRA, 1993; OLIVA et al., 2006). In our study, we did not survey the colonies more than once per month, so within-day variability could not be analyzed. Furthermore, the curve of circadian rhythms has not been developed for each month of the year, nor has the census methodology (terrestrial, by sea, aerial) bias been determined for these colonies. As no correction factor has yet been developed for Uruguayan colonies, the population size correction factors were based on the literature.

We applied two correction factors to the total numbers. The first correction was developed by CRESPO (1988) in northern Patagonia, who, from the known number of pups born and the survivorship schedule of life tables, estimated the total number of sea lions (DANS et al. 1996, 2004). From the relation between the total estimated $v s$. the total censed, the author obtained a correction factor of 1.8 for the total population. Here it was applied to both the terrestrial and aerial censuses of breeding and nonbreeding sites.

Secondly, we considered the correction factor applied by OLIVA et al. (2006) to aerial and ship based surveys of breeding and non-breeding sites in Chile of 1.02 which is applied to the whole population. In this case, the authors considered daily and weekly corrections based on the circadian rhythm data developed by SEPÚLVEDA et al. (2001).

\section{RESULTS}

\section{LAS PIPAS}

The number of animals counted and estimated with of the correction factors is shown in Table 1 . The maximum number of animals was recorded in July; however each species exhibited different monthly abundances. The Southern sea lion numbers were similar in June and July but increased in October and declined to 11 animals in November. Adult males were the most abundant category in June, July, November 2008, May and June 2009, being between 45.5 and $67 \%$. Subadult males were at their maximum in February $(64.7 \%)$ while females were at a maximum in October and December (47.5 and 64.3\% respectively) (Fig. 2).

On the other hand, South American fur seals were at a maximum in July and declined to $1 / 3$ of that number in October but were not observed in the area from November to February (Table 1). The trend in pinniped numbers is shown in Fig. 2b. The most frequent categories were females and juveniles (36-76\%) except in June 2009 when $65 \%$ of the total fur seals were adult males (Fig. 2b). It is interesting to note that except in November, pups of both species were always seen, especially in July when fur seal pups accounted for almost a third of the total.

Concerning the use of space, in Las Pipas, sea lions were found on the larger, flat rocks, while fur seals were more prevalent among sharper rocks and single smaller rocks on the islets. On some islets both species could be found, however in general they occupied different types of rocks (Fig. 3).

\section{Isla Verde-Islote Coronilla}

Sea lions were present in the area throughout the year, at its highest abundance in the breeding season. The number of animals counted at Isla Verde-Islote Coronilla varied between 225 and 521 which would be on the basis of 230 to 938 estimated animals, after applying the correction factors (Table 1). According to these figures, the sea lion colony at IV-IC represents between $5 \%$ and $9 \%$ at the most of the total Uruguayan population in Summer. 
Table 1. Number of Southern sea lions (Otaria flavescens) and South American fur seals (Arctocephalus australis) counted monthly at Las Pipas, and Southern sea lions counted at Isla Verde-Islote Coronilla. Correction factors: a: 1.02 according to Oliva et al. 2006, b: 1.8 according to Crespo 1988.

\begin{tabular}{lccc}
\hline Month & $\begin{array}{c}\text { O. flavescens } \\
\text { Counted (estimated) } \\
\text { Las Pipas }\end{array}$ & $\begin{array}{c}\text { A. australis } \\
\text { Counted (estimated) } \\
\text { Las Pipas }\end{array}$ & $\begin{array}{c}\text { O. flavescens } \\
\text { Counted (estimated) } \\
\text { Isla Verde-Islote La Coronilla }\end{array}$ \\
\hline $\begin{array}{l}\text { June 2008 } \\
\text { July 2008 }\end{array}$ & $90(92-162)$ & $70(71-126)$ & $225(230-405)$ \\
$\begin{array}{l}\text { September 2008 } \\
\text { October 2008 }\end{array}$ & $99(101-164)$ & $111(113-200)$ & $283(289-509)$ \\
November 2008 & $11(11-20)$ & $33(34-59)$ & $320(333-576)$ \\
$\begin{array}{l}\text { December 2008 } \\
\text { January 2009 }\end{array}$ & $14(14-25)$ & 0 & $452(461-814)$ \\
February 2009 & $17(17-31)$ & 0 & $477(487-859)$ \\
March 2009 & & 0 & $313 *(319-563)$ \\
May 2009 & $12(12-22)$ & $3(3-5)$ & $521(531-938)$ \\
June 2009 & $23(23-41)$ & $40(41-72)$ & \\
* underestimted value due to climatic conditions durg the flight and por coverage of pictures in the area
\end{tabular}

a

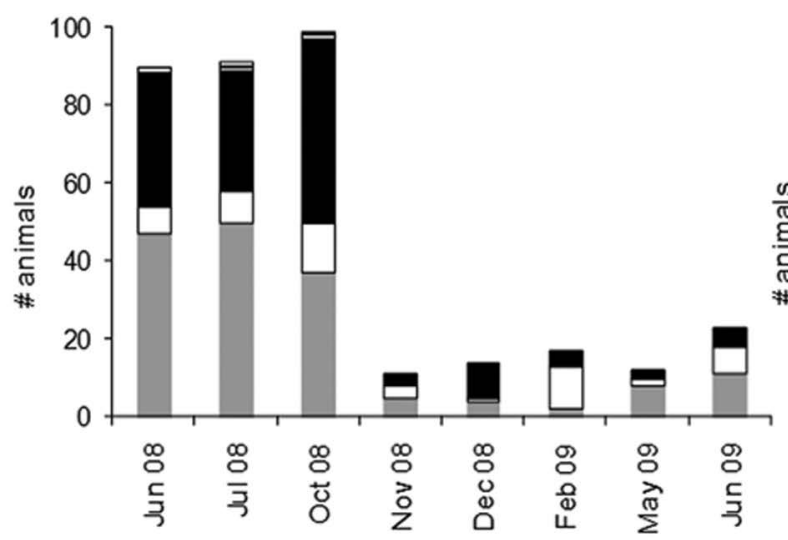

b

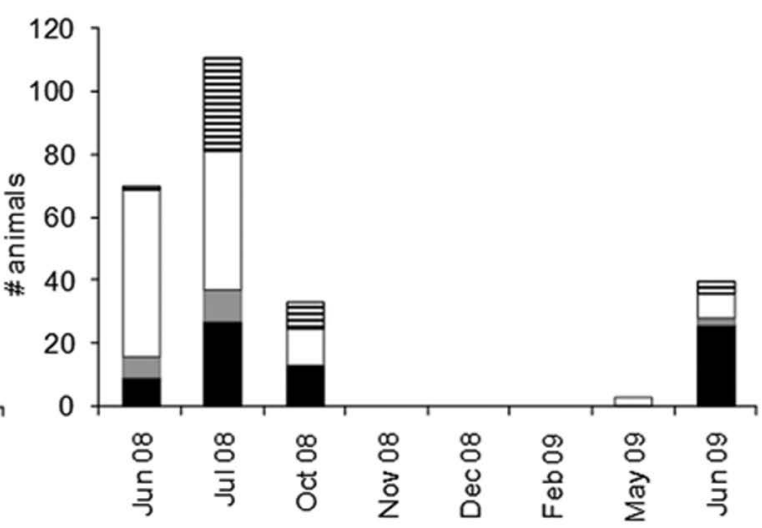

\section{- Females, $\square$ Adult males, $\square$ Subadult males, 目 Juveniles, 图 Pups}

Figure 2. Changes in the abundance of each age/sex category of each pinniped species at Las Pipas, Montevideo. a) Southern sea lions $(O$. flavescens) b) South American fur seals (A. australis).

The number of sea lions increased with time, being at a minimum in June and a maximum in January and March. Contrasting with LP, females were the most abundant category, varying between 32 and $72 \%$, except in September when adult males were the majority (38.6\%) (Fig. 3). The number of females doubled and sometimes trebled the number of adult males. In the other months females were the second most abundant, then the subadult males the juveniles, and the least abundant group being the pups. Pups were most abundant in March with 15 individuals (3.6\%) of total abundance, while no pups at all were observed in June, September, January and February (Fig. 3).

Isla Verde had a small number of animals (between 2 and 12) while most of the groups were concentrated on the Coronilla Islet. The distribution of the sea lion groups varied according to the season. In Winter sea lions were concentrated in the inner Coronilla islet, on a sandy beach substrate. The individuals were observed close to or in contact with each 


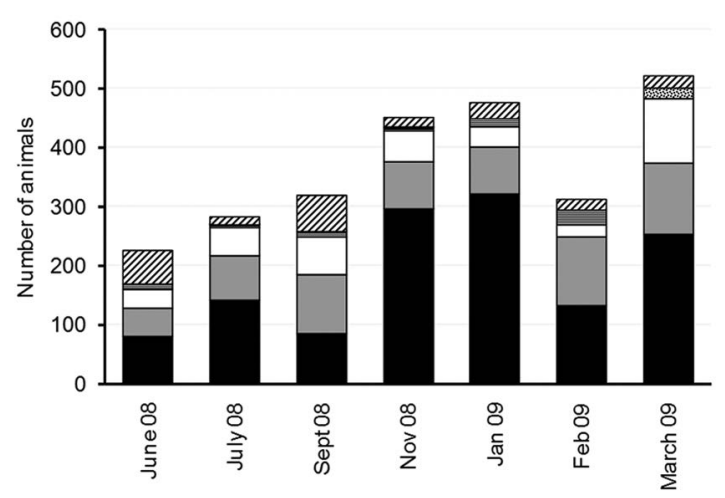

- Females, $\square$ Adult males, $\square$ Subadult males, 冒 Juveniles, 图 Pups, $\square$ Undetermined

Figure 3. Number of Otaria flavescens counted on each flight over Isla Verde-Islote La Coronilla. Females, Adult males, Subadult males, Juveniles, Pups, Undetermined

other. They were sighted in general on land, and none were observed near to the shore or in rocky areas (Fig. 4a).

In January and February many males were observed surrounded by a group of females, presumably harems. In September, sea lion groups were seen near the shore in contact with water on wet rocks (Fig. 4b). In Spring and Summer (November to March) the animals were scattered at greater distances from each other. The animals were situated in contact with the sea, near the shore, or in pools of water between the rocks, and on rocks off the Islet (Fig. 4c). In January on Isla Verde a formation of adult and subadult males was observed in an area known as the “area of single males" (VAZ-FERREIRA, 1975).

\section{DISCUSSION}

This study is a contribution to knowledge of two poorly known pinniped colonies off the Uruguayan coast. Otaria flavescens was present throughout the year on Isla VerdeIslote Coronilla, being most abundant in Summer. The number of sea lions in that area increased from June to November, representing an increase of at least 100 times since 1977 (PONCE DE LEÓN, 2000). In the case of Las Pipas, most animals may be immigrating from breeding areas. The area is mostly used by $O$. flavescens year-round, while $A$. australis was found mainly in Winter and the beginning of Spring. Both sexes and different age-categories, including pups were recorded, but no reproductive activity seems to occur. The maximum abundance was found in Winter, declined abruptly in Spring and remained very low in Summer.

Some possible contributory factors could be the movement of animals away from Isla de Lobos, maybe due to the disturbance caused by the capture of animals for their commercialization (PÁEZ, 2006), or because of the abundance or availability of food. This, combined with available living space for individuals that are starting to reproduce may have facilitated their colonization of new rookeries.

\section{TyPes OF COLONIES}

GRANDI et al. (2008) in northern Patagonia, defined breeding colonies as sites with $\geq 15$ pups during a reproductive season; otherwise they considered them non-breeding colonies. SEPÚLVEDA et al. (2001, 2011) classified colonies into breeding (presence of newborn pups) and non-breeding (absence of newborn pups). Both types of colonies differ not only by virtue of the prevailing activity but also because of the fluctuations in the number of animals during the year. So the abundance increases in Summer at reproductive sites but in the other seasons at the resting sites (SEPÚLVEDA, 2001).

The two areas counted presented different population structures. Isla Verde-Islote Coronilla has been defined as a breeding area for Southern sea lions (VAZ-FERREIRA, 1956). In this study, only in one month (March) there were more than 15 pups recorded. Because births occur in January (PONCE DE LEÓN, 2000), it was expected to find pups in January and February, however, no pups were, counted. There are two possibilities, either: 1) the area is still used as a breeding site and the presumably small number of pups in January and February was underestimated, due to their small size and the topography, mainly in rocky areas on the islands, and also due to the common behaviour of this species whereby they rest in very close proximity to or on top of one another (REYES et al., 1999, VAZ-FERREIRA, 1975). In March, when pups are bigger, the maximum number was counted, maybe because they were easier to detect. 2) The presence of pups in March could be the result of migration, because by that month they may be able to swim away from their natal colony (CAMPAGNA, 1985), and they could have just arrived in the area. Maybe we are detecting pups that have been born elsewere.

However, in the previous reproductive season, 20 pups were counted in January 2008 and 11 in April 2008 (LEZAMA and SZTEREN, 2009). Considering that the methodology used in this study does not allow one to see births taking place, it is difficult to know whether the pups were actually born there or had arrived from another colony. Further, formations suggestive of harems were seen on IV-IC, and the prevalence of females over other 

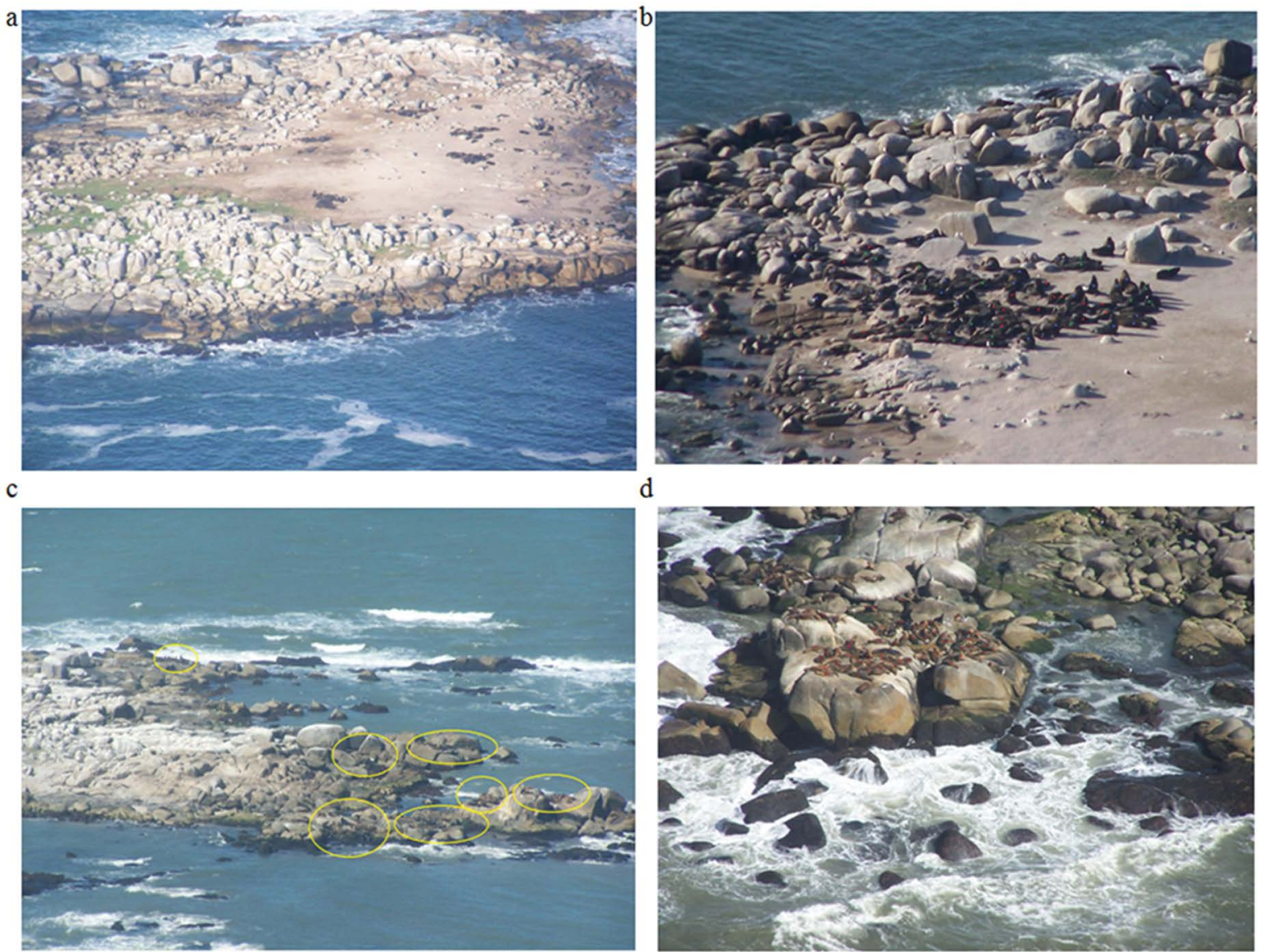

$\mathrm{d}$

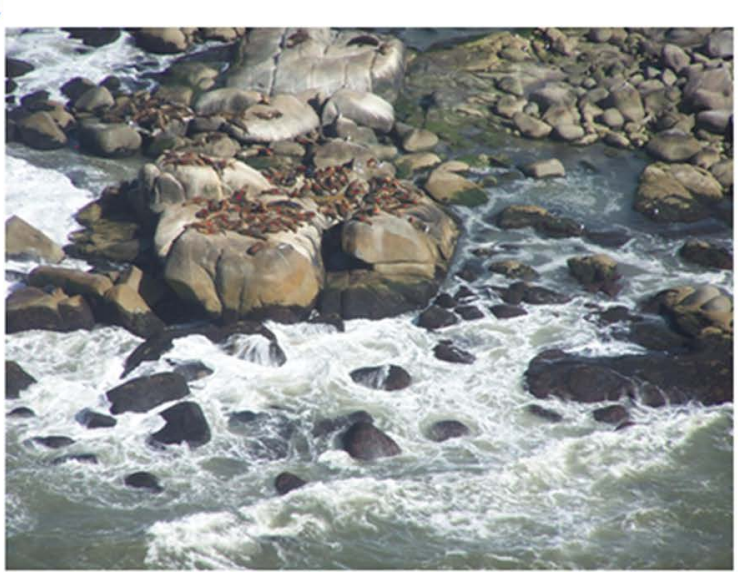

Figure 4. Localization of some sea lion groups a) dispersed on the beach, in June 2008; b) on the beach, more concentrated and near the sea in September 2008. c) on the rocks, in November 2008.

age categories is similar to the structure typical of other breeding areas (CRESPO and PEDRAZA, 1991; DANS et al., 1996; ACEVEDO et al., 2003; SEPÚLVEDA et al., 2011). I propose it could correspond to a colony with low breeding activity. It is important to note that this structure differs from that found in 1995 (PONCE DE LEÓN, 2000), where in Winter it was a haul-out site for sub-adults and adult males and in Summer there were females and pups, which would migrate afterwards to other Winter haul-outs.

Since 1953 there has been a dramatic decrease in the number of pups (from 500 to less than 20), and at the same time an exponential increase in the number of adults has occurred, this latter at least since 1977. We do not know how many adults there were on IV-IC in 1953 when 500 pups were born, but then the overall population of southern sea lions on the Uruguayan coast declined. Nowadays, due to the presence of adult males and females and the plausible harem formation it seems that adults have been growing steadily in number since 1977. Despite the number of pups being very low, we postulate that the area may be slowly increasing its breeding activity again. We hypothesize that sea lions are settling again on IV-IC and maybe the breeding activity will increase in the coming years. Furthermore, IV-IC is the only area which $O$. flavescens does not share with $A$. australis, this would therefore offer available space, on a sparcely urbanized coast, free of anthropogenic disturbance.

The evolution of previously unpopulated areas into breeding sites, with intermediate states of subadult males, juveniles and breeding groups is common in northern Patagonia for O. flavescens (DANS et al., 1996). In this sense, DANS (2004) and GRANDI et al. (2008) have described the establishment of small breeding areas inside haul-out sites, as a mechanism in the process of population expansion and recovery in Argentina. The process begins with the establishment of juveniles followed by their being joined by adult and/or subadult males, which results in mixed colonies that are ultimately transformed into breeding sites (GRANDI et al., 2008). In Chile, the increase of this species 
in the north would correspond to an increase in abundance in Perú (SIELFELD et al., 1997; BARTHELD et al., 2008). This process has also been reported among other pinniped species (e.g. Arctocephalus townsendi on San Benito Islands, Mexico, AURIOLES et al., 2010, and Arctocephalus gazella at Nyrøysa, Bouvet Island HOFMEYR et al., 2005). Due to the fact that in Uruguay, sea lion abundance is decreasing (PÁEZ, 2006), we suggest that this is not a process of expansion but rather a redistribution or displacement of individuals from other areas of the Uruguayan coast. Recent demographic models have suggested that animals are migrating from Isla de Lobos to the eastern rookeries (PÁEZ pers comm.). Additionally, the Cabo Polonio breeding rookeries located to the east of Isla de Lobos are also increasing (DIRECCIÓN NACIONAL DE RECURSOS ACUÁTICOS, 2012). Another evidence that supports this theory is the significant population increase of $O$. flavescens that took place at the Brazilian haulouts at Molhe Lleste and Ilha dos Lobos, Rio Grande do Sul, Brasil from 1993 to 2002 (PAVANATO et al., 2013). The monthly occupancy of these two haul-outs shows that sea lions arrive from Uruguayan breeding areas and return there for the subsequent reproductive season.

At Las Pipas, adult males, and females/juveniles were the predominant age classes. This defines it as a haul-out structure, being a resting area, especially for sea lions, but also for fur seals in Autumn and Winter. Grown-up pups of both species have been observed there, though only in Winter. Due to its structure and proportional abundances, Las Pipas is classified as a nonbreeding colony, it would mainly be used as a resting site within the feeding area. The months of maximum abundance coincide with other haul outs (e.g in southern Brazil, PAVANATO et al., 2013, Puerto Quequén, Argentina, GIARDINO et al., 2009). This new site may be explained by the response of some individuals to a higher availability of food. This is because the new haul-outs found in the present study are close to fishing ports. A similar situation has been recorded in Chile where a distribution change has been reported in relation to salmon farms in the South (OLIVA et al., 2006; SEPÚLVEDA et al., 2011) and in southern Brazil (Molhe Leste and Ilha dos Lobos haul-outs) fish abundance, mainly demersal teleosts on the continental shelf, may explain the linear, long-term increase in sea lion abundance (PAVANATO et al., 2013).

Fishery interactions increase in Autumn and Winter in Montevideo (DE MARIA et al., 2012, 2013) noting that once the breeding season has ended, the animals need to recover their physical condition. The increase in pinniped abundance at Las Pipas coincides with the period with the higher frequency of interactions at La Mulata fishing location, which is very close to Las Pipas (DE MARÍA et al., 2013). Sea lions which frequently interact with artisanal fisheries are sighted throughout the year at Las Pipas and during the Winter months mostly adult males are involved (SZTEREN and PÁEZ, 2002). It is interesting to note that only in June most fur seals at Las Pipas were adult males (65\%). This suggests that animals, including fur seals are using this haulout site while foraging in the area (DE MARÍA et al., 2012).

The age-sex composition at Las Pipas is very similar to that on the Ilha dos Lobos, Rio Grande do Sul, Brazil (SAN FELICE et al., 1999), which is a site for the seasonal resting and foraging of subadult males, especially of $O$. flavescens, while $A$. australis rarely occurs between Winter and Spring. At that site in 1994 the number of individuals started to increase in April, reaching a maximum in August and September, and then declined. Similarly, ROSAS et al. (1994) reported that Southern sea lions are present on the Rio Grande do Sul coast in large numbers from April to June. No reproductive activity is mentioned even though females were observed.

\section{USE OF SPACE}

At Isla Verde-Islote Coronilla, sea lions showed a seasonal variation in their abundance and use of space. The breeding season in Uruguay coincides with the hottest months (December to February). In this period the animals were seen to be more scattered and mostly near the shore. In Winter the animals concentrated in the inner area of the Islet, but in Summer the number of animals doubled and they expanded their occupancy area to the shore and the rocks in the sea. The use of pools of water, the greater proportion of animals in contact with the sea water and the decline of body contact were reported as thermoregulatory strategies for this species on the Isla de Lobos (BIANCO and VAZ-FERREIRA, 1993).

\section{RECOMMENDATIONS FOR FUTURE SURVEYS}

It would be important to collect observations and long term data to develop the management plan for IV-IC. These small islands lack organized tourist activity, and the continental surroundings are little urbanized. Consequently, it is necessary to continue monitoring this rookery on a seasonal basis, specially in Spring and Summer, in order to accompany the formation of harems and births and to determine the best moment to make a future census. I also suggest that demographic studies should be undertaken to quantify population parameters and detect trends on a longer temporal scale. These surveys would permit the confirmation of reproductive activity and whether this area becomes important as a breeding area. 
The Las Pipas area lacks any protective measures, being subject to disturbances caused by individuals who arrive in kayaks or sailing boats, and fishermen, whereas touristic trips are organized. At this haul-out, I also recommend that the area should continue to be monitored, to further understand the populational fluctuations that occur during the year.

To estimate the population size correction factors are necessary to account for the number of animals not detected by aerial photography, or from the sea, or because they were not onshore during the surveys. Unfortunately, there are no correction factors developed for aerial samplings for Uruguayan rookeries. It is to be recommended that correction factors should be calculated by, for example, undertaking aerial census and sea-terrestrial censuses simultaneously, by comparing the results of the two methods. It is important to mention that in Argentina the highest rates of increase were recorded at those sites that became rookeries or at those that do not represent an important contribution to the total number of sea lions in this population (DANS et al., 2004).

The occupation of new areas and/or the increase of rookeries with low breeding activity would be important for the whole population in Uruguay. The proportion of sea lions at Isla Verde-Islote Coronilla to the whole population is not so low; it could attain almost $10 \%$ of the whole Uruguayan abundance. The conservation of these colonies on the Uruguayan coast is thus vital, in view of the decline of the $O$. flavescens population. It is therefore necessary to continue monitoring the evolution of this colony especially considering that it have been included in the National Protected Areas System (SNAP). In the light of current recommendations of research in the region that have suggested that the population status of Southern sea lions in Uruguay should be investigated (DANS et al., 2012) by analyses such as this one, focused on little studied or almost unknown sites.

\section{ACKNOWLEDGEMENTS}

The author would like to thank the Oak FoundationDuke University Marine Laboratory mini-grants program for the financial assistance provided. I am also very grateful to the pilots of Rocha Aeroclub: Fabricio, Diego and Germán. Also I would like to thank Juan and Federico Ceriani, fishermen of La Mulata beach, Montevideo, who kindly took me to Las Pipas in order to make the pinniped counts. Special thanks are due to Elianne Castro who performed most of the aerial samplings in Isla Verde and helped with the data analysis. I am very grateful to Dr. Fernando Elorriaga and an anonymous reviewer who helped to improve the article.

\section{REFERENCES}

ACEVEDO, J.; AGUAYO-LOBO, A.; SIELFELD, W. Eventos reproductivos del león marino común, Otaria flavescens (Shaw, 1800), en el norte de Chile (Pacífico Suroriental). Rev. Biol. Mar. Oceanogr., v. 38, n. 2, p. 69-75, 2003.

AURIOLES-GAMBOA，D.; ELORRIAGA-VERPLANCKEN, F.; HERNÁNDEZ-CAMACHO, C. J. The current population status of Guadalupe fur seal (Arctocephalus townsendi) on the San Benito Islands, Mexico. Mar. Mamm. Sci., v. 26, n. 2, p. 402-408, 2010.

BARTHELD, J. L.; PAVÉS, H.; MANQUE, C.; VERA, C.; MIRANDA, D. Cuantificación poblacional de lobos marinos en el litoral de la I a IV Región. Informe Final Proyecto FIP 2006-50, 124 p, 2008. Available at: <http://www.fip.cl/FIP/ Archivos/pdf/informes/inffinal\%202006-50.pdf>. [Accessed on: 15 Jun. 2015].

BIANCO, J.; VAZ-FERREIRA, R. Comportamiento frente a cambios térmicos en Otaria flavescens y Arctocephalus australis en Isla de Lobos - Uruguay. Bol. Soc. Zool. Uruguay ( $2^{\mathrm{a}}$ época). Actas de la V Reunión Iberoamericana de Conservación y Zoología de Vertebrados, v. 8, p. 96-104, 1993.

CAMPAGNA, C. The breeding cycle of the southern sea lion, Otaria byronia. Mar. Mamm. Sci., v. 3, p. 210-218, 1985.

CRESPO, E. A. Dinámica poblacional del lobo marino del sur Otaria flavescens (Shaw, 1800), en el norte del litoral patagónico. 1988. 298 f. Tesis (Doctoral)- Facultad de Ciencias Exactas y Naturales, Universidad de Buenos Aires, 1988.

CRESPO, E. A.; PEDRAZA, S. N. Estado actual y tendencia de la población de lobos marinos de un pelo (Otaria flavescens) en el litoral norpatagónico. Ecología Austral, v. 1, n. 2, p. 87-95, 1991.

DANS, S. L.; CRESPO, E. A.; S. N; PEDRAZA, S. N.; GONZÁLEZ, R.; GARCÍA, N. Estructura y tendencia de los apostaderos de lobos marinos de un pelo (Otaria flavescens) en el norte de Patagonia. Informes Técnicos del Plan de Manejo Integrado de la Zona Costera Patagónica (Puerto Madryn, Argentina). Available at: <http://www.patagonianatural.org/ attachments/252_IT13.pdf $>$.

DANS, S. L.; CRESPO, E. A.; PEDRAZA, S. N.; KOENALONSO, M. Recovery of the South American sea lion (Otaria flavescens) population in northern Patagonia. Can. J. Fish. Aquat. Sci., v. 61, n. 9, p. 1681-1690, 2004.

DANS, S. L.; SIELFELD, W.; AGUAYO, A.; GIARDINO, G.; MANDIOLA, M. A. Estado y tendencia de las poblaciones. In: CRESPO, E. A.; OLIVA, D.; DANS, S.; SEPÚLVEDA, M. (Eds.). Estado de situación del lobo marino común en su área de distribución. Valparaíso: Universidad de Valparaíso, 2012. p. 18-35.

DE MARÍA, M.; GOLLUCHI, M.; SZTEREN, D. Registros de Arctocephalus australis (Carnivora Mammalia) interaccionando con la pesca artesanal en Uruguay. Bol. Soc. Zool. Uruguay, v. 21, n. 1-2, p. 50-58, 2012.

DE MARÍA, M. BARBOZA, F. R.; SZTEREN, D. Predation of South American sea lions (Otaria flavescens) on artisanal fisheries in the Rio de la Plata estuary. Fish. Res., v. 119, p. 69-73, 2013. 
DIRECCIÓN NACIONAL DE RECURSOS ACUÁTICOS, 2012. Development of information and key methodologies for the management of the seal population, Final report: Programa de Gestión Pesquera Proyecto FAO UTF/URU/025/ URU. Montevideo: MGAP- DINARA-FAO, 2012. 261 p.

EBERHARDT, L. L.; CHAPMAN D. G.; GILBERT, J. R. A Review of marine mammal census methods. Wildl. Monogr., v. 63, p. 5-46, 1979.

EFFORD, M. G.; DAWSON, D. K. Effect of distance-related heterogeneity on population size estimates from point counts. Auk, v. 126, n. 1, p.100-111, 2009.

GIARDINO, G. Estructura y dinámica de las colonias de lobos marinos de un pelo de la Provincia de Buenos Aires, y su relación con pesquerías de la región. 2014. 173 f. Tesis (Doctoral)Universidad Nacional de Mar del Plata, Mar del Plata, 2014

GRANDI, M. F.; DANS S. L.; CRESPO, E. A. Social composition and spatial distribution of colonies in an expanding population of South American sea lions. J. Mammal., v. 89, n. 5, p. 1218$1228,2008$.

HOFMEYR, G. J. G.; KRAFFT, B. A.; KIRKMAN, S. P.; BESTER, M. N.; LYDERSEN, C.; KOVACS, K. M. Population changes of Antarctic fur seals at Nyrøysa, Bouvetøya. Polar Biol., v. 28, n. 9, p. 725-731, 2005.

LEWIS, M. N.; XIMÉNEZ, I. Dinámica de la población de Otaria flavescens en el área de Península Valdés y zonas adyacentes. (Segunda parte). Cons. N. 79. Puerto Madryn: Centro Nacional Patagónico, 1983. 21 p.

LEZAMA, C.; SZTEREN, D. Situación del león marino sudamericano (Otaria flavescens) en el Área Costero Marina de Cerro Verde y sus zonas de influencia. Informe final para SNAP. Montevideo, 2009. Available at: $<$ http://www.scribd. com/doc/14056313/Sea-Lions $>$. [Accessed on: 15 Jun. 2015].

MINISTERIO DE VIVIENDA, ORDENAMIENTO TERRITORIAL Y MEDIO AMBIENTE. Decreto, Expte. 2005/05554, 2011. Available at: $<$ http://archivo.presidencia. gub.uy/sci/decretos/2011/08/mvotma_68.pdf>

OLIVA, D.; SIELFELD, W.; BUSCAGLIA, M.; MATAMALA, M. MORAGA, R.; PAVÉS, H.; PÉREZ, M. J.; SCHRADER, D.; SEPÚLVEDA, M.; URRA, A. Plan de acción para disminuir y mitigar los efectos de las interacciones del lobo marino común (Otaria flavescens) con las actividades de pesca y acuicultura. Informe Técnico Fondo de Investigación Pesquera IP-IT/2006-34. 2006, 75 p. Available at: <http://www.fip.cl/ FIP/Archivos/pdf/informes/inffinal\%202006-34.pdf>

PÁEZ, E. Situación de la administración del recurso lobos y leones marinos en Uruguay. In: MENAFRA, R.; RODRÍGUEZ-GALLEGO, L.; SCARABINO, F.; CONDE, D. (Eds.). Bases para la Conservación y el Manejo de la costa uruguaya. Montevideo: Vida Silvestre, Sociedad Uruguaya para la Conservación de la Naturaleza, 2006. p. 577-583.

PAVANATO, H.; SILVA, K. G; ESTIMA, S. C.; MONTEIRO, D. S.; KINAS, P. G. Occupancy dynamics of South American sea-lions in Brazilian haul-outs. Braz. J. Biol., v. 73, n. 4, p. 855-862, 2013.

PILLERI, G.; GIHR, M. Radical extermination of the South American Sea lion Otaria byronia (Pinnipaedia, Otariidae) from Isla Verde, Uruguay. Ostermundigen, v. 8, p. 15, 1977.

PONCE DE LEÓN, A. Sinopsis de la Biología y Ecología de las Poblaciones de Lobos Finos y Leones Marinos de Uruguay. Pautas para su Manejo y Administración. Montevideo: INAPE, MGAP, PNUD, 2000. 21 p. Available at: $<\mathrm{http}: / / \mathrm{www}$.dinara. gub.uy/files/lobos_marinos.pdf $>$. [Accessed on: 15 Jun. 2015].
RAUM-SURYAN, K. L.; PITCHER, K. W.; CALKINS, D. G.; SEASE, J. L.; LOUGHLIN, T. R. Dispersal, rookery fidelity, and metapopulation structure of Steller sea lions (Eumetopias jubatus) in an increasing and a decreasing population in Alaska. Mar. Mamm. Sci., v. 18, p. 746-764, 2002.

REYES, L. M; CRESPO, E. A.; SZAPKIEVICH, V. Distribution and population size of the southern sea lion (Otaria flavescens) in central and southern Chubut, Argentina. Mar. Mamm. Sci., v. 15, n. 2, p. 478-493, 1999.

ROSAS, F. C. W.; PINEDO, M. V.; Marmontel, M. M.; Haimovici, M. Seasonal Movements of the South American sea Lion (Otaria flavescens, Shaw) off the Rio Grande do Sul coast, Brazil. Mammalia, v. 58, n. 1, p. 51-59, 1994.

SANFELICE, D.; VASQUES, V. C.; CRESPO, E. A. Ocupação sazonal por duas espécies de Otariidae (Mammalia Carnivora) da Reserva Ecológica da Ilha dos lobos, Rio Grande do Sul, Brasil. Iheringia. Série Zoología, v. 87, p. 101-110, 1999.

SEPÚLVEDA, M.; OLIVA, D. P.; URRA, A.; PÉREZ-ÁLVAREZ, M. J.; MORAGA, R.; SCHRADER, D.; INOSTROZA, P.; MELO, A.; DÍAZ, H.; SIELFELD, W. Distribution and abundance of the South American sea lion Otaria flavescens (Carnivora: Otariidae) along the central coast off Chile. Rev. Chil. Hist. Nat., n. 84, p. 97-106, 2011.

SEPULVEDA, M.; OLIVA, D. P.; PALMA, F. J. Daily and annual circarhythms activity in the South American sea lion Otaria flavescens (Carnivora: Otariidae) at the central zone of Chile. Rev. Biol. Mar. Oceanogr., v. 36, n. 2, p. 181-187, 2001.

SIELFELD, W. C.; GUERRA, L. R.; DURÁN, E.; ACUÑA, A.; AGUAYO-LOBO, M.; SEPÚlVEDA, F.; PALMA, A.; MALINARICH, G.; CERDA, A.; BOLVARÁN, R.; GRAU, X.; VELOSO, Y.; GUERRA, M.; VARGAS, N.; AMADO, N.; PEREDO, R.; GALAZ, J. Monitoreo de la pesquería y censo del lobo marino común en el litoral de la I - IV Regiones. Valparaíso: Informe Final Proyecto Fondo de Investigación Pesquera, Subsecretaría de Pesca, 1997. $105 \mathrm{p}$.

SZTEREN, D.; PÁEZ, E. Predation by southern sea lions (Otaria flavescens) on artisanal fishing catches in Uruguay. Mar. Freshw. Res., v. 53, n. 8, p. 1161-1167, 2002.

VAZ-FERREIRA, R. Características Generales de las Islas Uruguayas Habitadas por Lobos Marinos. Trabajos sobre islas de lobos y lobos marinos. Montevideo: Servicio Oceanográfico y de Pesca del Ministerio de Industrias y Trabajo, 1956

VAZ-FERREIRA, R. Behavior of the southern sea lion, Otaria flavescens (Shaw) in the Uruguayan islands. Rapp. P.-v. Réun. Cons. Int. Explor. Mer., v. 169, n. 2, p. 19-227, 1975.

VAZ-FERREIRA, R. Otaria flavescens (Shaw), South American sea lion. In: FAO, UNEP. (Eds.). Mammals in the Seas. Small Cetaceans, Seals, Sirenians and Otters. Rome: FAO Fisheries, v. 5, n. 4, p. 477-495, 1982.

VAZ-FERREIRA, R.; LESSA, E.; ACHAVAL, F.; MELGAREJO, A. Recuento de cachorros de lobos marinos (Arctocephalus australis y Otaria flavescens) en Isla de Lobos, Uruguay, en febrero de 1981. Bol. Soc. Zool. del Uruguay, v. 2, p. 32-35, 1984.

XIMÉNEZ, I.; SCOLARO, J. A. Estado actual de las poblaciones de Pinnipedos del litoral Atlántico de la provincia del Chubut. Comisión Nacional de Estudios Geo-heliofísicos. Puerto Madryn: Centro Nacional Patagónico, 1974. 15 p. 